Hydrology and Earth System Sciences, 7(1), 123-131 (2003) C C EGU

\title{
Integrated hydrological modelling of a managed coastal Mediterranean wetland (Rhone delta, France): initial calibration
}

\author{
P. Chauvelon ${ }^{1}$, M.G.Tournoud ${ }^{2}$ and A. Sandoz ${ }^{1}$ \\ ${ }^{1}$ Fondation Sansouire, Station Biologique de la Tour du Valat, Le Sambuc, 13200 Arles, France \\ ${ }^{2}$ Hydrosciences, UMR 5569 CNRS-IRD-UM2, Univ. Montpellier, 2 Maison des Sciences de 1'Eau - 34095, Montpellier Cedex 5, France \\ Email for corresponding author: chauvelon@tourduvalat.org
}

\begin{abstract}
This paper presents a model of a heavily managed coastal Mediterranean wetland. The hydrosystem studied, called "Ile de Camargue", is the central part of the Rhone river delta. It comprises flat agricultural drainage basins, marshes, and shallow brackish lagoons whose connection to the sea is managed. This hydrosystem is subject to strong natural hydrological variability due to the combination of a Mediterranean climate and the artificial hydrological regime imposed by flooded rice cultivation. To quantify the hydrological balance at different spatial and temporal scales, a simplified model is developed - including the basin and the lagoons - using a time step that enables the temporal dynamic to be reproduced that is adapted to data availability. This modelling task takes into account the functioning of the natural and anthropogenic components of the hydrosystem. A conceptual approach is used for modelling drainage from the catchment, using a GIS to estimate water input for rice irrigation. The lagoon system is modelled using a two-dimensional finite element hydrodynamic model. Simulated results from the hydrodynamic model run under various hydro-climatic forcing conditions (water level, wind speed and direction, sea connection) are used to calculate hydraulic exchanges between lagoon sub units considered as boxes. Finally, the HIC ("Hydrologie de l'Ile de Camargue") conceptual model is applied to simulate the water inputs and exchanges between the different units, together with the salt balance in the hydrosystem during a calibration period.
\end{abstract}

Keywords: water management, conceptual hydrological model, hydrodynamic model, box model, GIS, Rhone delta, Camargue.

\section{Introduction}

In the Mediterranean area, coastal wetlands and their drainage basins are subject to very irregular climatic conditions and strong anthropogenic pressures. Such areas have been managed by man over many centuries, resulting in complex water management schemes. In deltaic areas, where topographic, and therefore hydraulic gradients, are very low, this complexity is increased.

The Rhone delta and its central part, the 'Ile de Camargue' and the Vaccarès lagoon system, located in the western part of the Mediterranean basin, south of France, is probably one of the best examples of strong inter-relationships between human activities and ecosystem evolution (Heurteaux, 1992, 1994). For decades the main agricultural activity in the basin has been flooded rice cultivation; this complex hydrosystem is particularly representative of human influences upon water and salinity regimes on a lagoon system that has been listed as an area for nature conservation since 1927.
Water resource management leads to increasingly complex situations with numerous conflicting objectives - often spatially related - and concerns dissimilar stakeholders. Decision support systems (DSS) for operational management or prospective purposes then become essential. However, methodological questions about the development and structure of operational DSS, still remain unanswered (Mysiak et al., 2002). The main step in the development of a DSS consists in linking hydrological processes and behavioural rules of 'actors' in a simple but dynamic representation of the hydrosystem defined as a complex system (Giraud et al., 2002). Fattorelli et al. (1998) developed a DSS that integrates a hydrological and hydrodynamic model for water inflows to the Venice lagoon (, but it remains a difficult task to deal with salt or nutrients balance in a coastal wetland (Gordon et al., 1996; Chauvelon, 1988; Dupra et al., 2000; La Jeunesse et al., 2002).

Multi-agent modelling is a promising way to describe the relationships linking water management and socio-economic 
processes (Barreteau and Bousquet, 2000). Franchesquin (2001) developed such an approach to describe the water cycle through the 'Ile de Camargue' hydrosystem. The work highlighted the advantages of such an integrated simulator to study alternative scenarios of economic development in the agricultural basin that are compatible with the ecological conservation of the lagoon. Nevertheless, this tool is neither designed nor used as a deterministic model to predict values with operationally acceptable spatial and temporal accuracy because of the crude approach to the physical processes.

The great complexity of the 'Ile de Camargue makes the analysis of the hydrological behaviour of the system a difficult task. Surface water flows within the basin are not only induced by rainfall but are also forced by the drainage of irrigated rice fields. Moreover, within the lagoons, water flows result from the combined effects of natural processes and human actions that control exchange with the sea. This paper develops a model to simulate the water cycle within the whole 'Ile de Camargue' hydrosystem, including the basin and the lagoons and is focussed on the calibration. Physical processes are introduced in the model conceptually and human influences are seen as the forcing variables. The model reproduces the temporal evolution of water levels and salinities in the lagoons under the combined effects of climatic and human forcings.

\section{Study site}

The 'Ile de Camargue hydrosystem is located in the Rhone delta, between the two branches of the river. A high embankment protects the basin from the floods of the River Rhone and from sea storms. The area includes flat agricultural drainage basins, marshes and shallow brackish lagoons whose connection to the sea is managed (Fig. 1).

\section{THE VACCARES LAGOONS}

The geometry of the lagoon system is complex; it can be divided in two sub systems: the Vaccares lagoon and the lower lagoons that are connected directly to the Mediterranean. The lower lagoons can be divided into two sub units: "Etang de l'Imperial" and "Etang du Lion" (EI and EL in Fig. 1). The lagoons are isolated from the surrounding salinas and salt works by an embankment.

When the water level in the Vaccares lagoon is at $0 \mathrm{~m}$ (a.m.s.l), the total area and volume of the lagoons are respectively $110 \mathrm{~km}^{2}$ and $10810^{6} \mathrm{~m}^{3}$. The lagoons store a total volume of about $16310^{6} \mathrm{~m}^{3}$ when the water level rises to $0.5 \mathrm{~m}$ (a.m.s.l).

\section{Water level and salinity data}

Water levels have been monitored continuously within the lagoons and on each side of the sea wall (Fig. 1) since 1993.

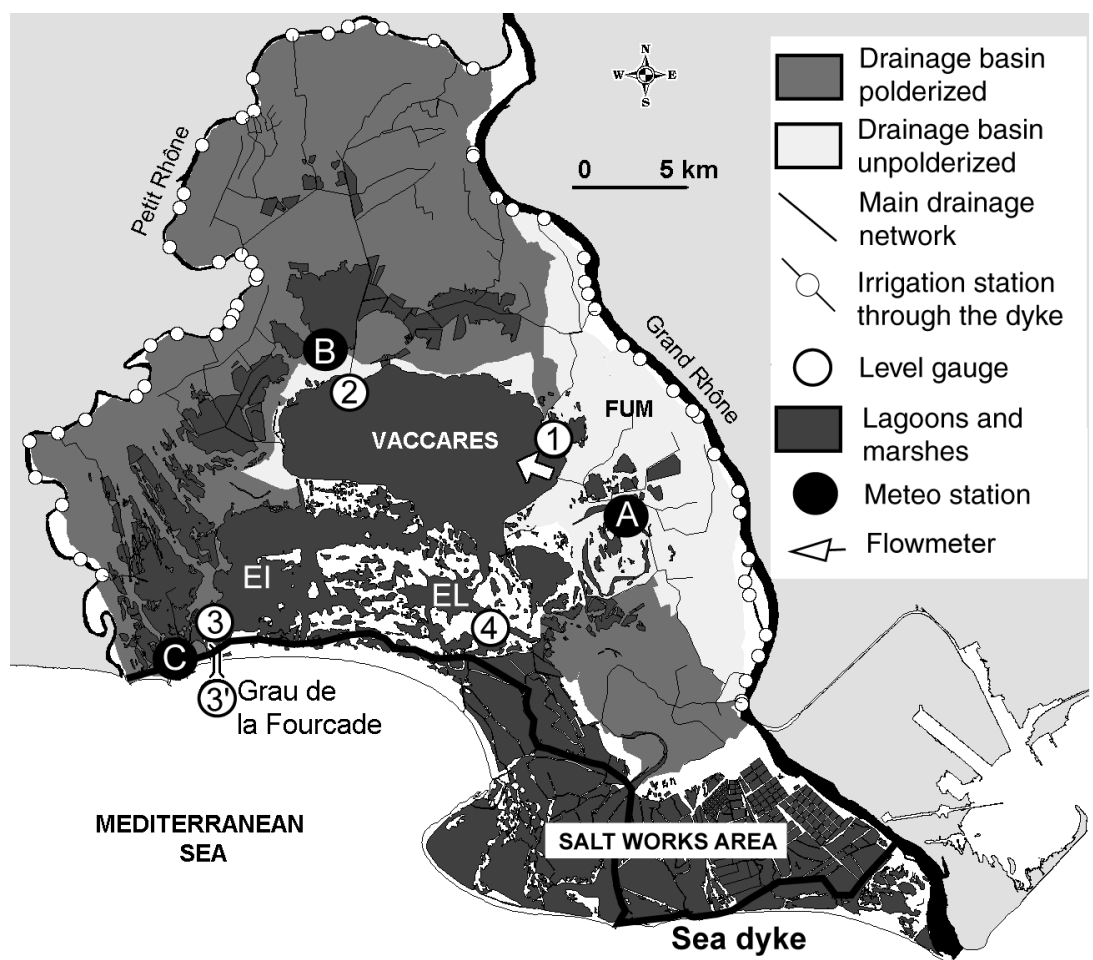

Fig. 1. Map of the 'Ile de Camargue'. 
Other water level data are available from 1968 to 1980, at ten locations in the Vaccares lagoon. Water salinity is measured monthly in six locations in the Vaccares lagoon and the lower lagoons since 1970.

\section{Bathymetry and vegetation}

The bathymetric data come from echo-sounding campaigns for the Vaccares lagoon and from manual depth measurements for the lower lagoons and the marshes. Maps of the sea grass bed are used to describe the hydraulic roughness in the hydrodynamic model (Vaquer and Heurteaux, 1989 ; Réserve Nationale de Camargue, unpubl. data).

\section{Wind and sea effects}

Water circulations in the lagoons are induced mainly by wind, measured continuously at points $\mathrm{A}$ and $\mathrm{C}$ on Fig. 1. Wind data (speed and direction) are recorded on a 30-min basis. Sea-lagoon exchanges through the sea wall at 'Grau de la Fourcade' are controlled by 13 manual sluice gates. In autumn and winter, the gates are opened only when northern winds are blowing to decrease water levels in the lagoons. In spring, one to three gates are opened, at least during the night, to allow fish recruitment into the lagoons (Pampoulie et al., 2001). Sea exchanges through the gates are mainly seawards.

\section{THE ILE DE CAMARGUE BASIN}

The basin (Fig. 1) consists of alluvial deposits from the River Rhone. The catchment area $\left(422 \mathrm{~km}^{2}\right)$ is relatively flat. The north and south-east of the delta (dark grey areas, Fig. 1) is devoted to intensive flooded rice cultivation. In this zone $\left(310 \mathrm{~km}^{2}\right)$, irrigation water is pumped from the Rhone and drainage water is returned to the river (or directly to the sea) by pumping. The freshwater marshes included in this area $\left(58 \mathrm{~km}^{2}\right)$ are devoted to hunting or are used for reed cultivation. The east delta (light grey areas, Fig. 1) drains into the Vaccares lagoon naturally by small low slope canals, mainly the Fumemorte canal (FUM in Fig. 1). In this zone $\left(87 \mathrm{~km}^{2}\right)$ agriculture is mainly flooded rice cultivation plus cattle breeding. In the lowlands surrounding the lagoons, large freshwater marshes $\left(25 \mathrm{~km}^{2}\right)$ are managed for waterfowl hunting, nature conservation, or exploited for their reed beds.

Important water volumes flow through the basin during the irrigation period of late spring and summer. In autumn and winter the basin is subject to short intense rainfalls.

\section{Hydro-meteorological data}

Rainfall data are collected by tipping bucket rain gauges at points A, B and C (Fig. 1). Daily potential evapotranspiration is calculated at the same sites, using the Penman (1948) method. At the outlet of the Fumemorte canal, discharges are monitored continuously using an automatic ultrasonic flow meter. The flow data are available on a tenminute basis with $10 \%$ accuracy.

\section{Geographical data}

Land use maps, from 1993 to 1998, are available from satellite image classifications (Landsat TM, ERS-2, and SPOT), using Geoimage ${ }^{\mathrm{TM}}$ software and integrated in a GIS tool (MapInfo ${ }^{\mathrm{TM}}$ ). Irrigation and drainage networks, pump locations and land parcel delineations are digitised from available maps and ortho-rectified aerial photographs. The annual areal extent of rice cultivation is extracted, together with data from associated pumping stations and drainage basins, for the period 1993-1998 (Chauvelon et al., 2001). Hydro-agricultural representative areas (HARA), adapted from the HRU (hydrological representative unit) concept (Flugel, 1996) are delineated from the land use maps and characterised in terms of land use and management schemes.

\section{Irrigation inputs}

All over the basin, rice is cultivated on levelled fields of 1 to $3 \mathrm{ha}$, delimited by bunds. The rice parcels are flooded during the crop period (from mid-April or early May, to September). Irrigation pumping stations (totalling 150 pumps) are managed either directly by the farmers or by cooperative associations (Gindre et al., 1999). For gauged irrigation systems, annual pumped volumes are estimated from given pump characteristics, duration of pumping and energy consumption. The irrigation depth versus rice area relationships are then calculated. Annual irrigation depths vary more for cooperative than for private irrigation systems (2100-5000 $\mathrm{mm}$ and $1500-3500 \mathrm{~mm}$, respectively). The estimated volume of water used for irrigation in the whole 'Ile de Camargue' varies between 296 and $36210^{6} \mathrm{~m}^{3}$ for the years 1996 and 1993 (Chauvelon et al., 2001).

A comparison of accumulated water inputs and outputs for the Fumemorte basin during a hydrological year is shown in Fig. 2.

\section{Modelling process}

The HIC model (Hydrologie de l'Ile de Camargue) evaluates the water inputs and/or exchanges between the different units, together with the salt balance in the hydrosystem. It considers each component within the hydrosystem, from the drainage basin to the sea, through the lagoons (Fig. 3). The HIC model integrates a drainage model for the basin and a box model for the lagoon and sea system. 


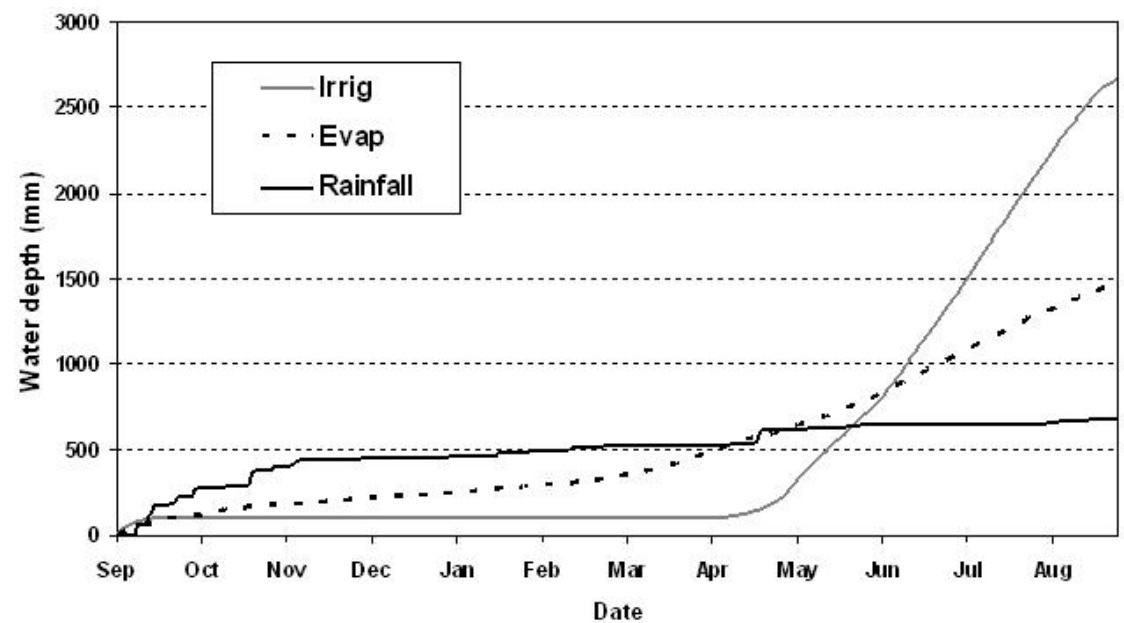

Fig. 2. Cumulative irrigation, rainfall and open water evaporation during the hydrological year 1994-1995 on the Fumemorte basin.

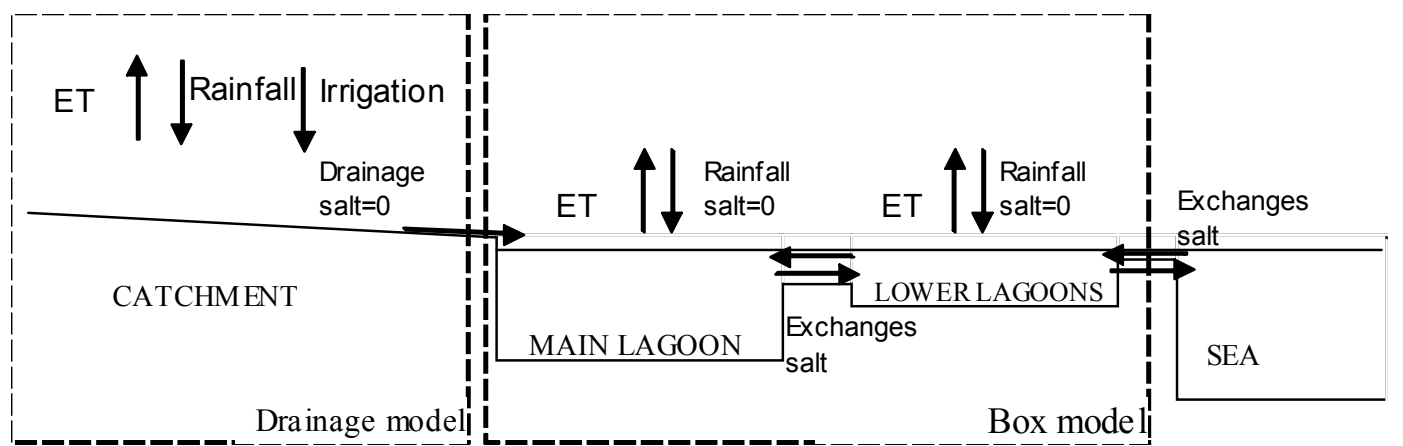

Fig. 3. Diagram of the coastal hydrosystem modelling concept.

\section{THE DRAINAGE MODEL}

Numerous hydrological rainfall-runoff models have been developed worldwide. These models are either conceptual models (lumped or distributed) or physically based distributed models. Physically based models (Beven, 1996, 2000; Refsgaard, 1997; Refsgaard and Abbott, 1996) take into account the detailed physical mechanisms in the water cycle: they include a lot of parameters. These models are powerful but difficult to operate, largely because of the large amount of data needed to calibrate them. Although not recent (Crawford and Linsley, 1963; Nash and Sutcliffe, 1970; Sorooshian and Gupta, 1983; Edijatno and Michel, 1989), conceptual models require fewer parameters, remain widely used since they are very efficient for rainfall runoff modelling when only limited data are available. Moreover the development of computational power and optimisation procedures make it possible to explore the behaviour of these models more efficiently (Yapo et al., 1998; Madsen, 2000; Hreiche et al., 2002) and to study in detail the continuing problem of the non-uniqueness of the parameter sets.
The drainage model here is based on the lumped conceptual approach of GR3 model (Edijatno and Michel, 1989). The hydrological functioning of the basin is represented by two reservoirs (Fig. 4). Rainfall and irrigation are the inputs. Potential evapo-transpiration affects the soil reservoir. The leakage of the routing reservoir is described by a linear equation with a single parameter.

Since only the Fumemorte canal is monitored, the three parameters of the drainage model will be calibrated on this sub-basin. The drainage model will be then extended to the whole basin, assuming a linear relationship with one parameter. The drainage model is integrated directly into the HIC model.

\section{LAGOONS-SEA : THE BOX MODEL}

The lagoon model adopts the point of view developed by Pous and Lazure (2002). The lagoon system is divided into three sub units (called boxes) that take into account its peculiar geometry (Fig. 1). It is assumed that exchanges between the boxes are essentially due to the horizontal 


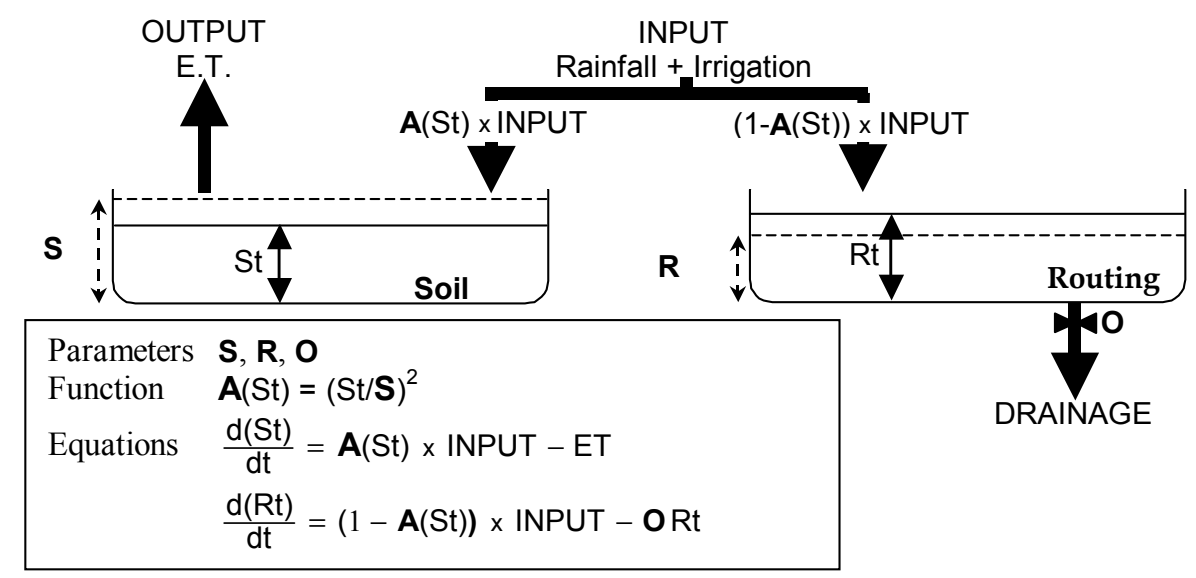

Fig. 4. Structure of the drainage basin model.

circulations induced by the wind, under given conditions of basin inputs and sea connection.

The wind induced currents are then calculated with the help of a two-dimensional hydrodynamic model. Several hydrodynamic models have been developed that can be applied to wetlands or coastal lagoons. In Mediterranean lagoons, either finite element (Umgiesser 1997; Covelli et al., 2002; Marsili-Libelli et al., 2002) or finite difference (Millet, 1989; Millet and Guelorget 1993) schemes have been used, according to the modelling tools which were operated. The RMA2 model, chosen in this study, is a 2D finite element scheme for subcritical free-surface flow solving the Reynolds form of the Navier Stockes equation (King and Norton, 1978).

The hydrodynamic model is applied to a domain that includes the Vaccares lagoon, the lower lagoons and the sea connection. Salinas and isolated marshes are not considered. The 2D space discretisation mesh (Fig. 5), based on triangular elements, comprises 5000 elements and 12000 nodes. Bed-friction coefficients are calibrated on observed water levels, assuming steady wind forcing and no tidal effect, under given boundary conditions (basin drainage inputs, sea water level and/or sea sluice state). The model outputs (current and water level maps) are processed to

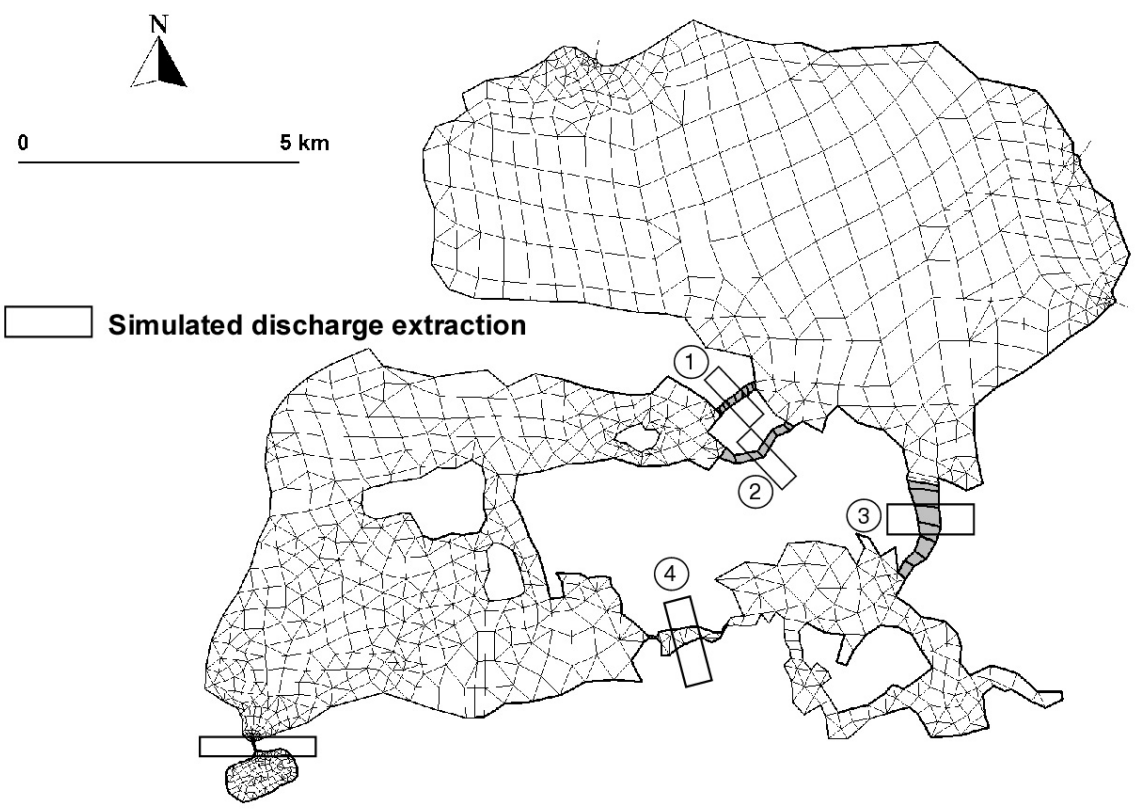

Fig. 5. Finite elements grid for the hydrodynamic model of the Vaccares and lower lagoons. 
calculate the exchanges through the straits across the limits between the sub-units (Fig. 5). These data are then used in the HIC model.

HIC MODEL - AN INTEGRATED MODEL FOR THE

\section{"ILE DE CAMARGUE" HYDROSYSTEM}

The HIC model considers the whole hydrosystem as a set of interrelated compartments, as shown in Fig. 6a. The drainage model outputs the total fresh water discharges into the lagoon. Four parameters need to be calibrated in the sea exchange model.

The lagoon is conceived as three boxes, characterised by volume and salinity. The boxes are subject to rainfall inputs, evaporation rates and fresh water discharges from the basin. It is assumed that the boxes are well mixed reservoirs (i.e. the most restrictive hypothesis in the box model) exchanging salt and water between each other and the sea.

The sea exchanges are modelled taking into account the sea sluice state. The discharge $\mathrm{Q}\left(\mathrm{m}^{3} \mathrm{~s}^{-1}\right)$ through the gates is calculated using a simple hydraulic formula:

$$
\mathrm{Q}=\mathrm{NS} \mathrm{m} \sqrt{\mathrm{H}}
$$

where $\mathrm{N}$ is the number of opened sluices, $\mathrm{S}\left(\mathrm{m}^{2}\right)$ is the area of one sluice, $\mathrm{H}(\mathrm{m})$ is the hydraulic head on the sluice (difference between the water levels measured on each side of the sluice).The discharge coefficient $\mathrm{m}$ is the only parameter in the model.

The salt exchanges between the boxes (or with the sea)

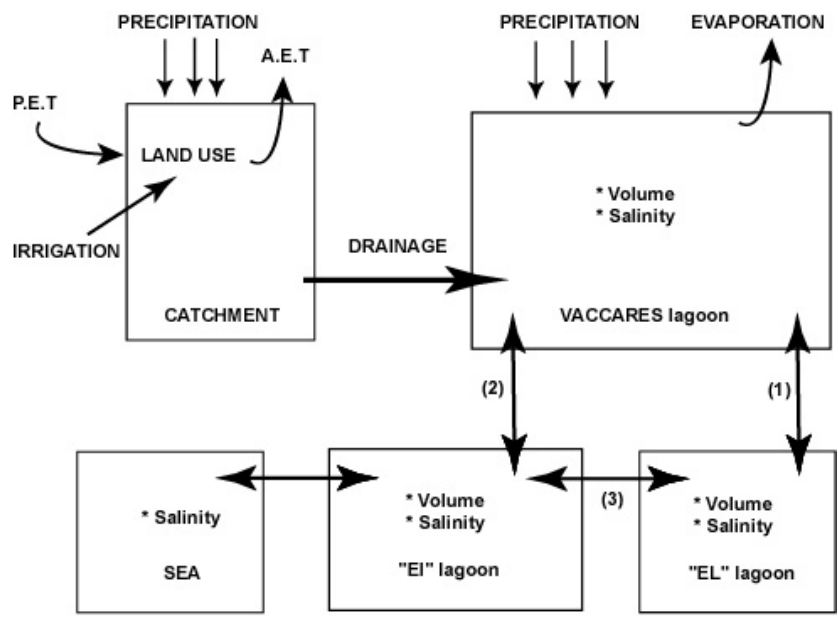

A.E.T : Actuel Evapo - Transpiration

P.E.T : Potentiel Evapo - Transpiration

(1), (2), (3) : hydraulic exchange functions derived from hydrodynamic model

Fig. 6a. Structure of the HIC integrated conceptual model of the hydrosystem. follow the well known mass conservation law (2) at a given time t:

$$
\frac{d\left(V_{i} S_{i}\right)}{d t}=\sum_{j \neq i} V_{j \rightarrow i} S_{j}-\sum_{j \neq i} V_{i \rightarrow j} S_{i}
$$

where $\mathrm{V}_{\mathrm{i}}$ and $\mathrm{S}_{\mathrm{i}}\left(\right.$ or $\mathrm{V}_{\mathrm{j}}$ and $\mathrm{S}_{\mathrm{j}}$ ) are the volume $\left(\mathrm{m}^{3}\right)$ and salinity $\left(\mathrm{gl}^{-1}\right)$ of the box $\mathrm{i}$ (or box $\mathrm{j}$ ), $\mathrm{V}_{\mathrm{j} \rightarrow \mathrm{i}}\left(\right.$ or $\mathrm{V}_{\mathrm{i} \rightarrow \mathrm{j}}$ ) is the volume exchanged $\left(\mathrm{m}^{3}\right)$ between the boxes $\mathrm{j}$ and $\mathrm{i}$ (or $\mathrm{i}$ and $\mathrm{j}$ ).

The HIC model is implemented using Vensim ${ }^{\mathrm{TM}}$ software. It runs on a daily time step for long periods. The input data are daily rainfall and potential evapo-transpiration, irrigation volumes, daily wind (daily average speed and direction), daily mean sea level and sea sluice state. The output data are daily volumes and salinity in the three lagoon boxes.

\section{Calibration and results}

The results presented in this paper concern the calibration tests conducted on a simplified version of the HIC model.

\section{THE DRAINAGE MODEL}

At the present time, apart from the Fumemorte basin, irrigation data are of poor quality. Only annual estimations are available, which are inappropriate for daily time step modelling. Moreover, the data set is not long enough to get a good calibration of the three parameters of the drainage model. So a simplified version of the drainage model was applied and is presented in this paper.

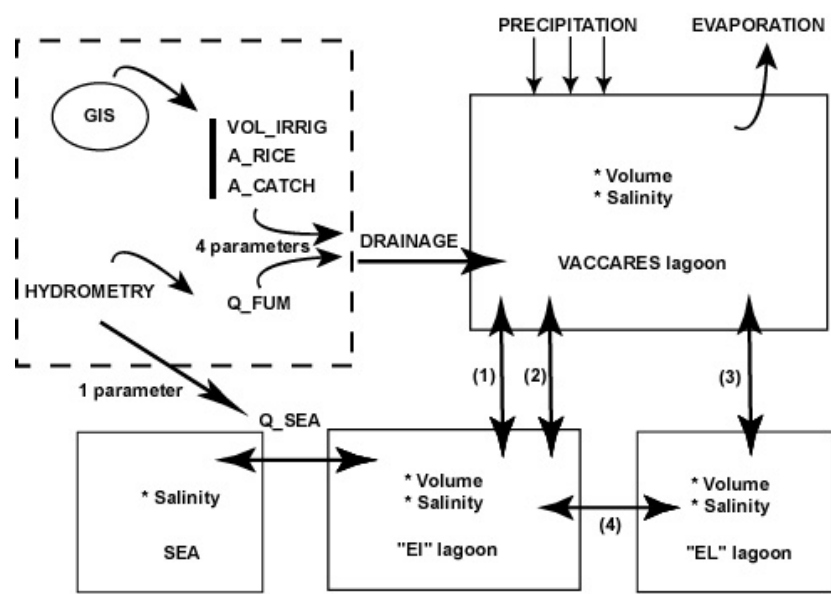

(1), (2), (3), (4) : hydraulic exchange functions derived from hydrodynamic mode VOL_IRRIG: seasonnal irrigation volume A_RICE: rice cultivated area A_CATCH: area of drainage basin

Fig. 6b. Provisional modelling process used in the HIC model. 
It is assumed that the daily discharge from the whole basin can be evaluated directly from the Fumemorte discharge. The relationship between the discharges involves four parameters and is written as:

$$
\mathrm{DT}=\mathrm{DF}\left[\alpha(1-\mathrm{RS})\left(\frac{\mathrm{AT}}{\mathrm{AF}_{\mathrm{F}}}\right)^{\beta}+\beta \mathrm{RS}\left(\frac{\mathrm{AIRT}}{\mathrm{AIRF}}\right)^{\beta}\right]
$$

where $\mathrm{D}$ is the daily discharge, $\mathrm{A}$ the basin area, and AIR the rice irrigated area; subscripts $\mathrm{F}$ and $\mathrm{T}$ denote the Fumenmorte and total drainage basin respectively. RS is equal to 1 during the rice growing season and to zero for the rest of the time. This equation is directly integrated within the HIC model (Fig 6b).

\section{LAGOONS-SEA MODEL}

The hydrodynamic model has been run for 60 simulations, under various scenarios of boundary and forcing conditions. Steady conditions are assumed that can be gathered in (a) low basin drainage inputs, in spring, with open sea sluices and various sea water level and wind conditions; (b) high basin drainage inputs, in summer, with closed sea sluices and light winds; (c) high basin drainage inputs, in autumn and winter, with open sea sluices and strong northern winds. The exchanges between the boxes are processed from the model outputs. It is found that basin drainage inputs have little effect on the exchanges between the boxes inside the lagoon system. The exchanges depend on wind speed and direction (Table 1). For a given wind direction, it is possible to link exchange volumes to wind speed, for each box. These relationships are integrated into the HIC model.

\section{HIC MODEL CALIBRATION}

The simplified version of the HIC model has five parameters: four for the basin and one for the exchanges between the lagoons and the sea.

The calibration was undertaken using data from April 1994 to September 1995. The five parameters were optimised using the optimising tool integrated in Vensim ${ }^{\text {тм }}$ software. The optimisation process works in a multi criterion (Powell, 1977) mode and tries to minimise simultaneously the cumulative squared difference between observed versus simulated water levels and salinities in Vaccares and in the lower lagoons.

The calibration gives good results for the Vaccares lagoon, as shown in Fig. 7. The validation is now in progress.

\section{Conclusion}

The HIC model has been developed as the first step towards an operational water management tool for 'Ile de Camargue'
Table 1. Example of simulation results for water velocities in channel 1 between Vaccarès and EI lagoon, for SE wind under different drainage input and wind speed. (Drainage $=$ discharge from the catchment; $\mathrm{W}=$ wind speed $10 \mathrm{~m}$ above ground; Level 1 = water level in channel 1; Water velo. = depth-averaged mean water velocity in the channel).

\begin{tabular}{lccc}
\hline $\begin{array}{l}\text { Drainage } \\
\left(\mathrm{m}^{3} \cdot \mathrm{s}^{-1}\right)\end{array}$ & $\begin{array}{l}\text { W. Speed } \\
\left(\mathrm{m} \cdot \mathrm{s}^{-1}\right)\end{array}$ & $\begin{array}{c}\text { Level 1 } \\
(\mathrm{m} \text { a.m.s.l })\end{array}$ & $\begin{array}{c}\text { Water velo. } \\
\left(10^{-2} \mathrm{~m} \cdot \mathrm{s}^{-1}\right)\end{array}$ \\
\hline 1.5 & 1 & 0.42 & -0.7 \\
1.5 & 2 & 0.42 & 0.6 \\
1.5 & 3 & 0.41 & 1.7 \\
1.5 & 4 & 0.4 & 2.7 \\
4.1 & 3 & 0.51 & 1.0 \\
4.1 & 6 & 0.49 & 5.3 \\
4.1 & 3 & 0.54 & 1.0 \\
4.1 & 5 & 0.48 & 2.7 \\
6.5 & 8 & 0.56 & 14.1 \\
\hline
\end{tabular}
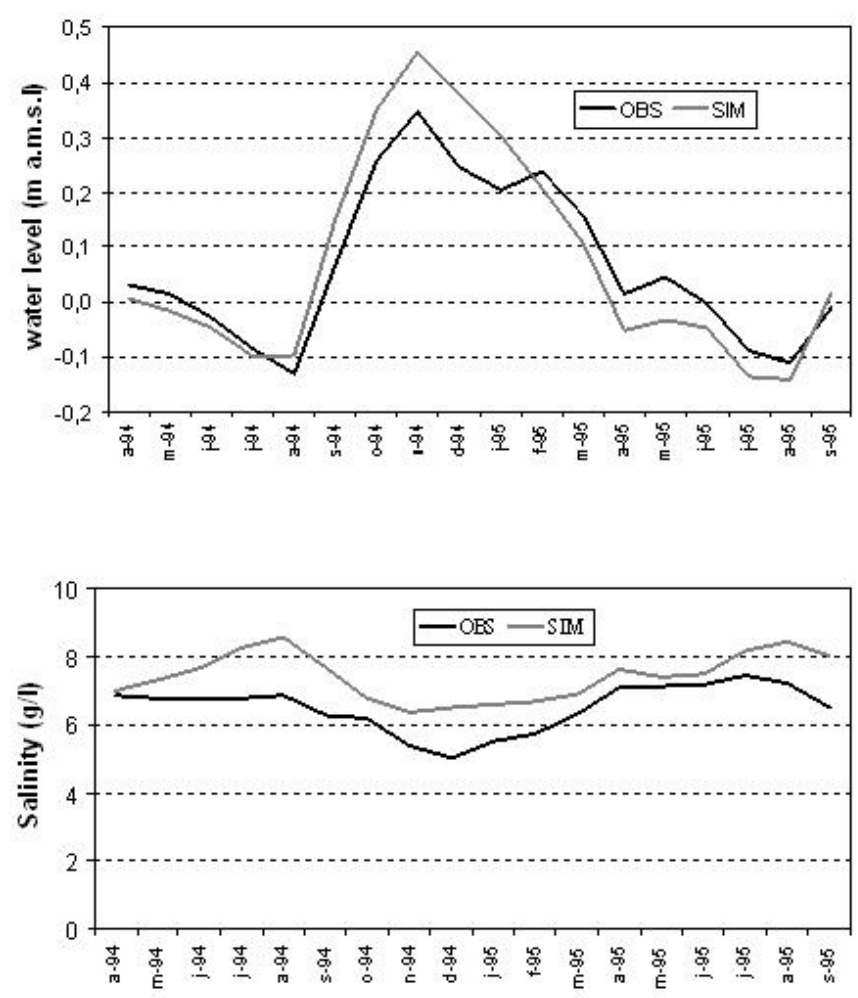

Fig. 7. Comparison of observed (OBS) and simulated (SIM) values of Vaccares lagoon level and salinity, for the calibration period (April 94 to September 1995).

and the Rhone delta (France). The model simulates the components of the water cycle with a conceptual approach at the hydrosystem scale, including the drainage basin and the lagoon system. The integrated model assimilates GIS 
data in the conceptual drainage model together with the results from a deterministic hydrodynamic model for the lagoon modelling. A simplified version of the HIC model has been developed.

The calibration tests, whilst encouraging, show the need for improvement of the data set. To operate correctly, the HIC model uses several input variables whose accuracy plays an essential role in calibration. The periods for which good quality data are available are rather limited at present so it is necessary to continue field data collection.

The first validation tests are in progress, together with modelling improvements. The complete drainage model will be implemented in the HIC model structure. The hydrodynamic model is always under improvement, extra simulations are necessary to determine the relationship between the exchanges and the wind speed, especially for strong winds. In its present version, the HIC model does not take into account the processes of marine and hyper saline water intrusion (Heurteaux, 1992) through the bottom of the lower lagoons when sea level is above lagoon level. To complete the salt balance of the lagoon system, those processes have to be modelled. In the context of rising sea levels relative to the delta, this phenomenon will become more important for future applications of the model.

Notwithstanding the desirability of ensuring the number of physical processes modelled explicitly for simulating the water cycle in the complex 'Ile de Camargue' hydrosystem, continuing development of the model will include socioeconomic issues to ensure the operative effectiveness of this tool of management.

\section{References}

Barreteau, O., Bousquet, F., 2000. SHADOC: a multi-agent model to tackle viability of irrigated systems. Ann.Oper. Res., 139162.

Baumgartner, M.F. and Apfl, G. M., 1996. Remote sensing and geographic information systems. Hydrolog. Sci. J. 43, 593-607.

Beven, K.J., 1993. Prophecy, reality and uncertainty in distributed hydrological modelling. Adv. Water Resour., 16, 41-51.

Beven, K.J., 1996. A discussion of distributed modelling, Chapter 13A. In: Distributed Hydrological Modelling, J-C. Refsgaard and M.B. Abbott (Eds.), Kluwer, Dordrecht, the Netherlands. 255-278.

Beven, K.J., 2000. Uniqueness of place and process representations in hydrological modelling. Hydrol. Earth Syst. Sci., 4, 203213.

Chauvelon P., Sandoz A., Heurteaux, V. and Berceaux, A., 2001. Satellite remote sensing and GIS used to quantify water input for rice cultivation (Rhône delta, France). IAHS Publ. no. 267. 446-450.

Chauvelon, P., 1996. Hydrologie quantitative d'une zone humide méditerranéenne aménagée: le bassin de Fumemorte en Grande Camargue, delta du Rhône. Thèse de Doctorat, Univ. Montpellier 2 USTL, 275pp.
Chauvelon, P., 1998. A wetland managed for agriculture as an interface between the Rhône river and the Vaccarès lagoon (Camargue, France): transfers of water and nutrients. Hydrobiologia 373/374, 181-191.

Covelli, P., Marsili-Libelli, S. and Pacini, G., 2002. SWAMP: A two-dimensional hydrodynamic and quality modelling platform for shallow waters. Numer. Methods Partial Differ. Eqns, 18, 663-687.

Crawford, N.H. and Linsley, R.K., 1963. A conceptual model of the hydrologic cycle. IAHS Publication no. 63, 573-587.

Christiaens, K. and Feyen, J., 2001. Analysis of uncertainties associated with different methods to determine soil hydraulic properties and their propagation in the distributed hydrological MIKE SHE model. J. Hydrol., 246, 63-81.

Droogers, P. and Kite, G., 2002. Remotely sensed data used for modelling at different hydrological scales. Hydrol. Process., 16, 1543-1556.

Dupra, V., Smith, S.V., Marshall, J.I., and Crossland, C.J., 2001 Coastal and estuarine systems of the Mediterranean and Black Sea region: carbon, nitrogen, and phosphorus fluxes. LOICZ Reports \& Studies No. 19, i + 101 pages, LOICZ IPO, Texel, the Netherlands.

Edijatno, N. and Michel, C., 1989. Un modèle pluie-débit journalier à trois paramètres. La Houille Blanche, 2, 113-121.

Fattorelli, S., Da Ros, D., and Coccato, M., 1998. SALVE: An integrated hydrological and hydrodynamic model for the simulation of water inflows to the Venice lagoon. Proc. $3^{\text {rd }}$ Int. Conf. Hydroinformatics, Copenhagen, 24-26 August 1998. Balkema, Rotterdam, ISBN 9054109831. 1349-1356.

Flugel, W., 1996. Delineating hydrological response units by geographic information system analysis for regional hydrological modelling using PRMS/MMS in the drainage basin of the river Brol, Germany. Hydrol.Process., 9, 423-436.

Franchesquin, N., 2001. Modélisation et simulation Multi-Agents d'écosystèmes anthropisés : une application à la gestion hydraulique en Grande Camargue. Thèse d'informatique, Université de Droit, d'Économie et des Sciences d'AixMarseille, Aix-Marseille III, $250 \mathrm{pp}$.

Franchini, M., Galeati, G. and Berra, S., 1998. Global optimization techniques for the calibration of conceptual rainfall-runoff models. Hydrolog. Sci. J., 433, 443-458.

Gindre, D., Heurteaux, P. and Vianet, R., 1999. Les infrastructures d'irrigation et de drainage sur le territoire du Parc naturel régional de Camargue. Courrier du Parc n 48/49, 44-83.

Giraud, F., Lanini, S., Rinaudo, J.D., Petit, V. and Courtois, N., 2002. An innovative modelling concept for integrated water resources management linking hydrological functioning and socio-economic behaviour - The Hérault catchment case study, south of France. Proc. Int. Environmental Modelling and Software Soc. meeting 2002. 126-131.

Gordon, Jr., D.C., Boudreau, P.R., Mann, K.H., Ong, J.-E., Silvert, W.L., Smith, S.V., Wattayakorn, G., Wulff, F. and Yanagi, T., 1996. LOICZ Biogeochemical Modelling Guidelines. LOICZ Reports \& Studies No 5, 1-96.

Heurteaux, P., 1992. Modifications du régime hydrique et salin des étangs du système Vaccarès (Camargue, France) liées aux perturbations anthropiques des cinquantes dernières années. Annls Limnol., 28, 157-174.

Heurteaux, P., 1994. Essai de quantification des termes du bilan hydrique des étangs du système Vaccarès (Camargue, France). Annls Limnol., 30, 131-144.

Hreiche, A., Mezher, D., Bocquillon, C., Dezetter, A., Servat, E. and Najem, W., 2002. Parallel processing for a better understanding of equifinality in hydrological models. Proc. Int. Environmental Modelling and Software Society meeting 2002. 410-415. 
King, I.P. and Norton, W.R., 1978. Recent Applications of RMA's Finite Element Models for Two-Dimensional Hydrodynamics and Water Quality. Proc. 2nd Int. Conf. on Finite Elements in Water Resources, London. 281-299.

La Jeunesse, J.M., Deslous-Paoli, J.M., Ximénès, M.C., Cheylan, J.P., Mende, C., Borrero, Scheyer, C. and Scheyer, L., 2002. Changes in point and non point sources phosphorus loads in the Thau catchment over 25 years (Mediterranean Sea - France). Hydrobiologia 475/476, 403-411.

Madsen, H., 2000. Automatic calibration of a conceptual rainfallrunoff model using multiple objectives. J. Hydrol., 235, 276288.

Marsili-Libelli, S., Pacini, G. and Covelli, P., 2002. Application of a Two dimensional Hydrodynamic Model for Shallow Waters to the Orbetello Lagoon. Proc. 5th Int. Conf. Hydroinformatics, Cardiff, UK. 371-375.

Millet, B., 1989. Fonctionnement hydrodynamique du bassin de Thau. Validation écologique d'un modèle numérique de circulation. Oceanologica Acta, 12, 37-46.

Millet, B. and Guélorget, O., 1993. Relationship between benthic communities and physical environment in a lagoon ecosystem. J. Coastal Research, 9, 378-389.

Mysiak, J., Giupponi, C. and Fassio, A., 2002. Decision Support for Water Resource Management: An Application Example of the MULINO DSS. Proc. Int. Environmental Modelling and Software Society meeting 2002, 138-143.

Nash, J.E. and Sutcliffe, J.V., 1970. River flow forecasting through conceptual models. J. Hydrol., 273, 282-290.

Pampoulie, C., Chauvelon, P., Rosecchi, E., Bouchereau, J.L. and Crivelli, A.J., 2001. Environmental factors influencing the gobiid assemblage of a Mediterranean Lagoon: empirical evidence from a long term study. Hydrobiologia, 445, 175-181.

Penman, H.L., 1948. Natural evaporation from open water, bare soil and grass. Proc. Roy. Soc. London Ser. A, 193, 120-145.
Post, D.A. and Jakeman, A.J., 1999. Predicting the daily streamflow of ungauged catchments in S. E. Australia by regionalising the parameters of a lumped conceptual rainfallrunoff model. Ecol. Mod., 123, 91-104.

Pous, S., Lazure, P., 2002. Seasonal and annual circulation in Arabian Gulf. Proc. JONSMOD/MEDMOD, Liège, Juillet, 2002. 247-252.

Powell, J.M.D., 1977. Restart procedures for the conjugate gradient method. Math. Program., 12, 241-254.

Rango, A. and Shalaby, A.I., 1996. Operational applications of remote sensing in hydrology: success, prospects and problems. Hydrolog. Sci. J., 43, 947-968.

Refsgaard, J.C. and Abbott, M.B., 1996. The role of distributed hydrological modelling in water resources management. In: Distributed Hydrological Modelling, M.B Abbott and J.C. Refsgaard (Eds.), Kluwer, the Netherlands. 1-16.

Refsgaard, J.C., 1997. Parameterisation, calibration and validation of distributed hydrological models. J. Hydrol., 198, 69-97.

Sorooshian, S. and Gupta, V.K., 1983. Automatic calibration of conceptual rainfall-runoff models: the question of parameter observability and uniqueness. Water Resour. Res. 191, 260-268.

Tournoud, M.G., Dezetter, A. and Salles, C., 2001. Paramétrisation du fonctionnement d'un karst dans un modèle global: exemple de la Vène, (Hérault, France). UNESCO, PHI-V/Documents techniques en hydrologie/ $n^{\circ} 51.275-282$.

Umgiesser G., 1997. Modelling the Venice Lagoon. Int. J. Salt Lake Res., 6, 175-199.

Vaquer, A. and Heurteaux, P., 1989. Modifications récentes de la végétation aquatique de l'étang du Vaccarès (Camargue, France) liées aux perturbations anthropiques. Ann. Limnol., 25, 25-38.

Yapo, P.O., Gupta, H.V. and Sorooshian, S., 1998. Multiobjective global optimization for hydrologic models. J. Hydrol., 204, 8397. 
